\title{
PENGARUH UMUR POTONG TERHADAP BOBOT AKHIR DAN BOBOT KARKAS AYAM BROILER
}

\author{
Yana Wati ${ }^{1}$, Harapin Hafid ${ }^{2}$, Rahman ${ }^{2}$ \\ ${ }^{1}$ Alumnus Fakultas Peternakan Universitas Halu Oleo \\ ${ }^{2}$ Dosen Fakultas Peternakan Universitas Halu Oleo \\ email : yhanawathy1294@gmail.com
}

\begin{abstract}
ABSTRAK
Penelitian ini bertujuan untuk mengkaji pengaruh umur potong terhadap bobot akhir dan bobot karkas ayam broiler. Sebanyak 96 ekor ayam yang digunakan dalam penelitian ini. Penelitian ini menggunakan rancangan acak lengkap (RAL) dengan 4 perlakuan dan 3 ulangan. Variabel yang diamati adalah bobot akhir, bobot karkas dan persentase karkas ayam broiler. Data yang diperoleh dianalisis berdasarkan analisis ragam. Jika perlakuan berbeda nyata dilakukan uji lanjut menggunakan uji beda nyata terkecil. Berdasarkan hasil penelitian perbedaan umur potong ayam broiler berpengaruh yang sangat nyata $(p<0,01)$ terhadap bobot akhir, bobot karkas dan persentase karkas ayam broiler. Disimpulkan bahwa umur potong berpengaruh terhadap bobot akhir, bobot karkas dan persentase karkas ayam broiler.
\end{abstract}

Kata kunci : Ayam broiler, umur potong, bobot akhir, bobot karkas, persentase karkas.

\begin{abstract}
This research aimed to evaluate the effect of slaughtering age on final and carcass weight of broiler chicken. As many 96 of broiler chickens were used in this research. This research used completely randomized design with 4 treatments and 3 replications. Obtained variables were final weight, carcass weight, and carcass percentage of broiler chicken. Data were analyzed based on analysis of variance. If treatment was significantly different, it will be tested continuously by using least significant different test. According to result of this research, the difference of slaughtering age of broiler chicken has very real effect $(\mathrm{P}<0.01)$ on final weight, carcass weight, and carcass percentage of broiler chickens. It could be concluded that slaughtering age can affect the final weight, carcass weight, and carcass percentage of broiler chicken.
\end{abstract}

Key words: Broiler chicken, slaughtering age, final weight, carcass weight, percentage of carcass.

\section{PENDAHULUAN}

Permintaan konsumen terhadap produk peternakan terus meningkat sebagai akibat dari laju pertambahan jumlah penduduk dari tahun ke tahun. Selain itu kesadaran masyarakat terhadap pentingnya pemenuhan gizi mengakibatkan terjadinya peningkatan konsumsi pangan asal hewan (Hafid, 2008). Salah satu produk peternakan yang disukai masyarakat Indonesia adalah daging ayam broiler. Jumlah produksi 
daging ayam ras pedaging mencapai 1.628.307 ton pada tahun 2015 dan meningkat menjadi 1.689 .584 ton pada tahun 2016 (BPS, 2016).

Ayam broiler adalah ayam pedaging yang biasanya dipanen pada umur sekitar 58 minggu. Pertumbuhan ayam broiler cepat karena berasal dari seleksi yang intensif menghasilkan ras yang homogen serta mampu menghasilkan karkas dan daging yang banyak (Hafid, 2011). Hal tersebut dapat dicapai dengan manajemen pemeliharaan yang baik dan didukung kualitas ransum yang tinggi (Manurung, 2011).

Salah satu faktor yang menentukan keberhasilan suatu usaha peternakan ayam broiler adalah umur potong. Produksi, kualitas daging serta tingkat keuntungan akan tercapai secara optimal jika peternak mampu memprediksi kapan ternaknya harus dipotong dan diselaraskan dengan permintaan pasar serta konversi pakan yang efisien. Umur potong ayam pedaging yang ideal di antara 4-6 minggu karena persentase karkas relatif sama sekitar $(69-70 \%$ ) dengan bobot hidup tidak terlalu besar (Kadiran dan Kushartono, 2005).

Karkas pada ayam adalah bagian dari tubuh ayam setelah dipotong tanpa darah, bulu, kepala, kaki, leher dan organ dalam. Umumnya karkas dibagi menjadi beberapa bagian. Bagian-bagian dari karkas tersebut dapat disebut dengan potongan karkas komersial, yang terdiri atas bagian paha, dada, punggung, dan sayap. Pemotongan karkas menjadi potongan komersial dapat meningkatkan daya jual, sehingga konsumen dapat dengan bebas memilih bagian mana yang disukai dan dibutuhkan untuk pengolahan lebih lanjut (Hafid dan Hasnudi ,2001; Hafid, 2011)

Hafid (2011) menyatakan bahwa faktor yang mempengaruhi produksi karkas dan daging unggas adalah umur ternak saat dipasarkan, jenis kelamin, genetik, asupan nutrisi dan lingkungan. Soeparno (2009) menyatakan faktor yang dapat mempengaruhi kualitas karkas antara lain dalah genetik, spesies, bangsa, tipe ternak, jenis kelamin, umur, pakan termasuk bahan aditif dan stress.

Sehubungan dengan hal tersebut, penelitian ini akan dilakukan untuk mengkaji pengaruh umur potong terhadap bobot akhir dan bobot karkas ayam broiler, data dan informasi tentang hal tersebut masih relatif kurang dan hasilnya masih sangat bervariasi.

\section{MATERI DAN METODE}

\section{Materi Penelitian}

Penelitian menggunakan 96 ekor ayam broiler dengan sampel yang dianalisis sebanyak 12 ekor ayam broiler dengan umur 2, 3, 4 dan 5 minggu. Kandang yang digunakan adalah kandang litter dengan ukuran 1 meter x 1 meter dengan kepadatan 8 ekor ayam broiler per petak kandang.

\section{Metode Penelitian}

Penelitian ini menggunakan rancangan acak lengkap (RAL) dengan 4 perlakuan dan 3 ulangan. Variabel yang diamati adalah bobot akhir, bobot karkas dan persentase karkas. Data yang diperoleh disusun dan dianalisis berdasarkan analisis ragam. Jika perlakuan berbeda nyata dilakukan uji lanjut menggunakan uji BNT (beda nyata terkecil). 


\section{HASIL DAN PEMBAHASAN}

\section{A. Bobot Akhir}

Bobot akhir merupakan bobot ayam yang ditimbang sebelum dipotong setelah ayam dipuasakan selama 6 jam. Bobot akhir ayam broiler pada berbagai umur pemotongan yang berbeda disajikan pada Tabel 1.

Tabel 1. Bobot akhir (g) Ayam Broiler pada Berbagai Umur Pemotongan yang Berbeda

\begin{tabular}{ccccc}
\multirow{2}{*}{ Ulangan } & \multicolumn{4}{c}{ Umur Pemotongan } \\
\cline { 2 - 5 } & 2 minggu & 3 minggu & 4 minggu & 5 minggu \\
\hline 1 & 651,00 & 1155,00 & 1600,00 & 2130,00 \\
2 & 738,00 & 1130,00 & 1616,00 & 2093,00 \\
3 & 630,00 & 1100,00 & 1516,00 & 2159,00 \\
\hline Rataan & $673,00^{\mathrm{d}}$ & $1128,33^{\mathrm{c}}$ & $1577,33^{\mathrm{b}}$ & $2127,33^{\mathrm{a}}$ \\
\hline SD & 57,26 & 27,54 & 53,72 & 33,08 \\
\hline
\end{tabular}

Keterangan : Superskrip yang berbeda pada baris yang sama menunjukkan perlakuan berbeda sangat nyata $(p<0,01)$.

Berdasarkan hasil pengamatan pada Tabel 1. didapatkan bobot akhir tertinggi pada umur pemotongan 5 minggu yaitu 2127,33 g, sedangkan bobot akhir yang terendah pada umur pemotongan 2 minggu sebesar $673,00 \mathrm{~g}$.

Hasil analisis ragam menunjukan bahwa pemotongan dengan berbagai umur yang berbeda menunjukkan pengaruh yang sangat nyata $(p<0,01)$ terhadap bobot akhir ayam broiler. Dari hasil data yang diperoleh terlihat bahwa secara signifikan rataan bobot akhir semakin meningkat dengan bertambahnya umur. Hal ini sesuai dengan pendapat Hafid dkk. (2010) dan Hafid (2005) yang menyatakan bahwa proporsi jaringan tulang, daging, dan lemak akan dipengaruhi oleh umur, bangsa, bobot tubuh, jenis kelamin dan makanan. Menurut Soeparno (2009) menyatakan bahwa bobot potong dipengaruhi oleh pertambahan bobot badan dan umur ternak, sedangkan pertambahan bobot badan dipengaruhi oleh asupan nutrien.

Perbandingan bobot akhir ayam broiler pada umur pemotongan yang berbeda dapat dilihat pada Gambar 1.

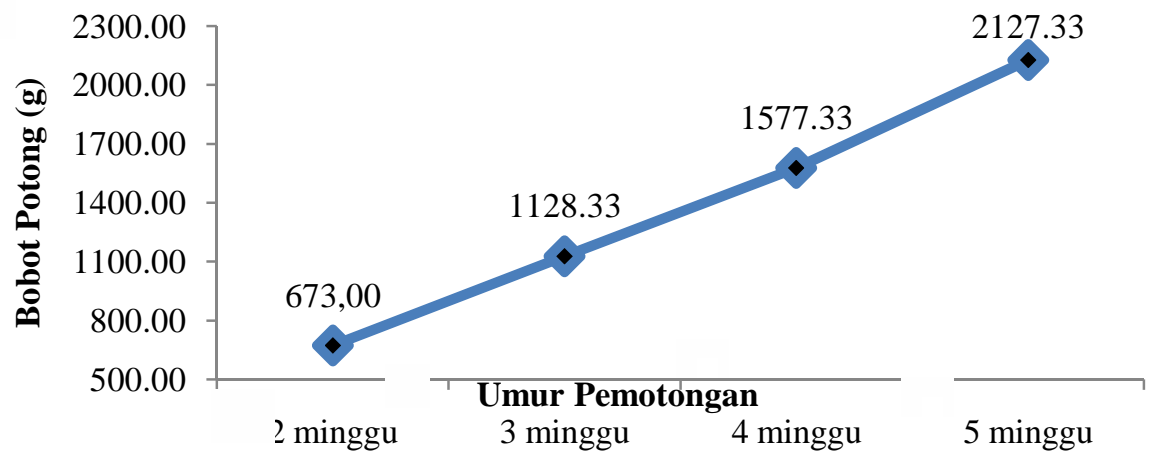

Gambar 1. Perbandingan Bobot Akhir Ayam Broiler pada Umur Potong yang berbeda 
Gambar 1. menunjukkan bahwa bobot akhir ayam broiler meningkat seiring dengan peningkatan umur potong. Semakin tinggi umur potong yang broiler, maka bobot akhir akan semakin meningkat. Hal ini sesuai dengan hasil penelitian Marlina (2016) dimana faktor umur memberikan pengaruh yang sangat nyata $(p<0,01)$ terhadap bobot potong ayam kampung. Umur potong menunjukan adanya signifikan yang sangat nyata karena semakin bertambahnya umur ternak akan meningkatkan bobot potong.

\section{B. Bobot Karkas}

Bobot karkas diperoleh dari hasil penimbangan ayam tanpa darah, bulu, kepala sampai batas pangkal leher, kaki sampai batas lutut, dan organ dalam (jeroan). Bobot karkas ayam broiler pada berbagai umur pemotongan yang berbeda disajikan pada Tabel 2.

Tabel 2. Bobot Karkas Ayam Broiler pada Berbagai Umur Pemotongan yang Berbeda

\begin{tabular}{ccccc}
\hline \multirow{2}{*}{ Ulangan } & \multicolumn{4}{c}{ Umur Pemotongan } \\
\cline { 2 - 5 } & 2 minggu & 3 minggu & 4 minggu & 5 minggu \\
\cline { 2 - 5 } & $\mathrm{g}$ & $\mathrm{g}$ & $\mathrm{g}$ & $\mathrm{g}$ \\
\hline 1 & 366,60 & 675,60 & 973,20 & 1172,35 \\
2 & 383,60 & 673,20 & 978,40 & 1205,35 \\
3 & 364,00 & 652,45 & 989,40 & 1235,88 \\
\hline Rataan & 371,40 & 667,08 & 980,33 & 1204,53 \\
\hline SD & 10,65 & 12,73 & 8,27 & 31,77 \\
\hline
\end{tabular}

Keterangan : Superskrip yang berbeda pada baris yang sama menunjukkan perlakuan berbeda sangat nyata $(p<0,01)$.

Berdasarkan hasil pengamatan pada Tabel 2. didapatkan bobot karkas tertinggi pada umur pemotongan 5 minggu yaitu 1204,53 g, sedangkan bobot karkas yang terendah pada umur pemotongan 2 minggu sebesar 371,40 g.

Hasil analisis ragam menunjukan bahwa pemotongan dengan berbagai umur yang berbeda menunjukkan pengaruh yang sangat nyata $(p<0,01)$ terhadap bobot karkas ayam broiler. Dari hasil data yang diperoleh terlihat bahwa secara signifikan rataan bobot karkas semakin meningkat dengan bertambahnya umur. Hal ini sesuai dengan pendapat Hafid dkk (2010) dan Hafid (2005) yang menyatakan bahwa proporsi jaringan tulang, daging, dan lemak akan dipengaruhi oleh umur, bangsa, bobot tubuh, jenis kelamin dan makanan.

Perbandingan bobot karkas ayam broiler pada umur pemotongan yang berbeda dapat dilihat pada Gambar 2. 


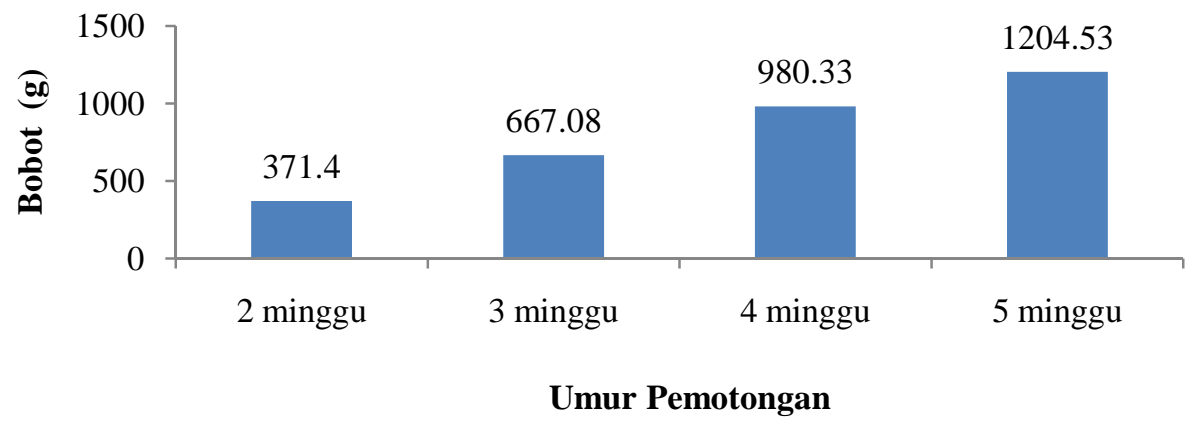

Gambar 2. Perbandingan Bobot Karkas Ayam Broiler pada Umur Pemotongan yang Berbeda

Gambar 2. Menunjukkan bahwa umur pemotongan berbanding lurus dengan bobot karkas ayam broiler. Semakin bertambahnya umur maka bobot karkas ayam broiler semakin meningkat pula. Hal ini sejalan dengan hasil penelitian Indra dkk (2015) yang menyatakan bahwa bobot karkas akan bertambah dengan bertambahnya umur dan bobot badan, dimana rata-rata bobot karkas ayam yang paling besar yaitu ayam Sentul Jantan umur pemotongan 12 minggu. Bobot karkas pada minggu 12 sebesar 694,16 g. Bobot karkas pada umur potong 12 minggu lebih besar disebabkan oleh umur pemeliharaan yang lebih lama dibandingkan dengan pemeliharaan enam, delapan dan sepuluh minggu.

\section{Persentase Karkas}

Bobot karkas diperoleh dari hasil penimbangan ayam tanpa darah, bulu, kepala sampai batas pangkal leher, kaki sampai batas lutut, dan organ dalam (jeroan). Persentase karkas ayam broiler pada berbagai umur pemotongan yang berbeda disajikan pada Tabel 3 .

Tabel 3. Persentase Karkas Ayam Broiler pada Berbagai Umur Pemotongan yang Berbeda

\begin{tabular}{ccccc}
\hline \multirow{3}{*}{ Ulangan } & \multicolumn{4}{c}{ Umur Pemotongan } \\
\cline { 2 - 5 } & 2 minggu & 3 minggu & 4 minggu & 5 minggu \\
\cline { 2 - 5 } & $\%$ & $\%$ & $\%$ & $\%$ \\
\hline 1 & 56,31 & 58,49 & 60,83 & 55,04 \\
2 & 51,98 & 59,58 & 60,54 & 57,59 \\
3 & 57,78 & 59,31 & 65,26 & 57,24 \\
\hline Rataan & $55,36^{\mathrm{c}}$ & $59,13^{\mathrm{b}}$ & $62,21^{\mathrm{bc}}$ & $56,62^{\mathrm{a}}$ \\
\hline SD & 3,02 & 0,56 & 2,65 & 1,38 \\
\hline
\end{tabular}

Keterangan : Superskrip yang berbeda pada baris yang sama menunjukkan perlakuan berbeda sangat nyata $(p<0,01)$. 
Hasil analisis ragam menunjukkan bahwa persentase karkas ayam broiler pada umur pemotongan yang berbeda menunjukan perbedaan yang sangat nyata $(\mathrm{P}<0,01)$. Persentase karkas ayam broiler meningkat seiring dengan bertambahnya umur. Indra dkk. (2015) mengemukakan bahwa persentase karkas dipengaruhi oleh umur potong, semakin lama umur potong maka akan semakin besar persentase karkasnya.

Berdasarkan hasil pengamatan pada Tabel 3. didapatkan persentase paha tertinggi pada umur pemotongan 4 minggu yaitu $62,21 \%$, sedangkan persentase paha yang terendah pada umur pemotongan 2 minggu yaitu 55,36\%. Persentase karkas ayam broiler dalam penelitian ini sejalan dengan hasil penelitian Kadiran dan Kushartono (2005) dimana pada pemotongan umur 2 minggu $(59,62 \%), 4$ minggu $(68,84 \%)$, dan 6 minggu $(70,58 \%)$, dengan rata-rata kenaikan dari 2 ke 4 minggu sekitar 15,47\% dan 4 ke 6 minggu sekitar 2,53\%. Umur potong berpengaruh terhadap persentase hasil karkas, semakin bertambah umur, semakin tinggi persentase karkas yang diperoleh .

Perbandingan persentase karkas ayam broiler pada umur pemotongan yang berbeda dapat dilihatada Gambar 3.

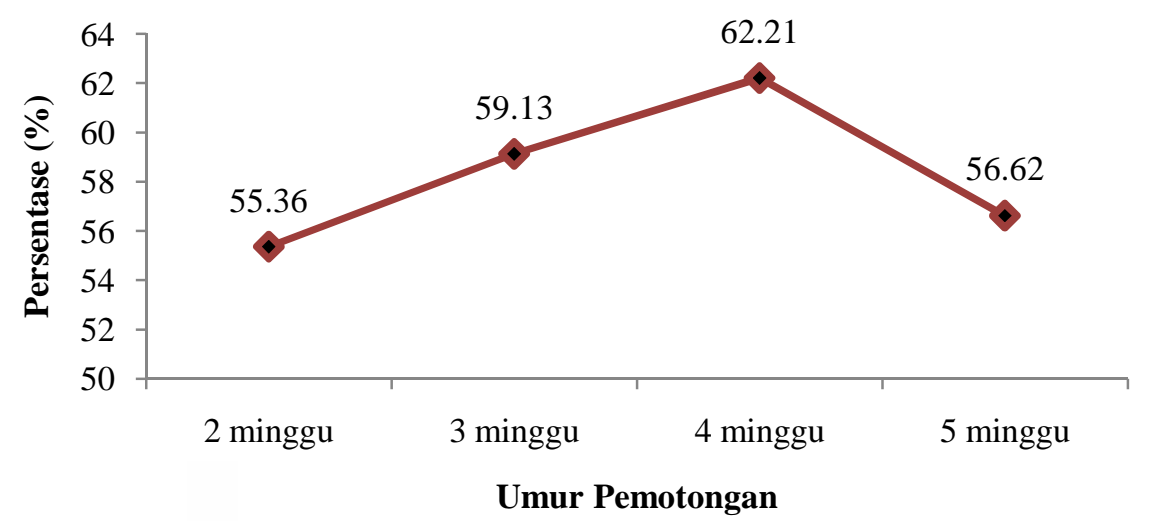

Gambar 3. Perbandingan Persentase Karkas Ayam Broiler pada Umur Pemotongan yang Berbeda

Gambar 3. menunjukkan bahwa persentase karkas maningkat dari umur pemotongan 2 minggu sampai 4 minggu dan menurun pada umur pemotongan 5 minggu. Salah satu faktor yang mempengaruhi persentase karkas ayam broiler adalah bobot hidup. Persentase karkas merupakan perbandingan bobot karkas dengan bobot hidup, sehingga bobot hidup yang besar akan diikuti pula oleh bobot karkas yang besar begitupun sebaliknya (Hafid, 1998; Soeparno 2009).
Data pada Tabel 3. menunjukkan bahwa pada minggu kelima mengalami penurunan persentase karkas. Hal ini dikarenaka pada umur 5 minggu ayam tidak mengalami pertumbuhan lagi namun sudah terjadi pembentukan lemak. Menurut Suhardi (2011) mengatakan bahwa dengan meningkatnya umur dan fase produksi dan reproduksi ayam betina mengalami penurunan bobot badan. 


\section{KESIMPULAN}

Dapat disimpulkan bahwa umur potong berpengaruh terhadap bobot akhir, bobot karkas dan persentase karkas ayam broiler. Sehingga untuk memperoleh karkas yang menguntungkan, umur pemotongan ayam broiler yang lebih optimal adalah umur 4 minggu.

\section{DAFTAR PUSTAKA}

BPS (Badan Pusat Statistik). 2016. Produksi Daging Ayam Ras Pedaging Menurut Provinsi, 2009-2016. Jakarta.

Brake. J., G.B. Havesten, S.E. Scheideler, F.R. Ferket and D.V. Rives. 1993. Relationship of sex, age and body weight to broiler carcass yield and ofal production. Poult. Sci. 71 : 1137-1145.

Hafid, H. 1998. Kinerja produksi sapi Australian Comercial Cross yang dipelihara secara feedlot denga kondisi bakalan dan lama penggemukan yang berbeda. Tesis. Program Pascasarjana. Institut Pertanian Bogor. Bogor.

Hafid, H. \& Hasnudi. 2001. Pengaruh pemberian pakan komersial terhadap karkas ayam pedaging. Majalah Ilmiah Kultura. Fakultas Pertanian, Universitas Sumatera Utara, Medan. ISSN. 01261665. Nomor. 144 (1): 30-38.

Hafid, H. 2005. Kajian pertumbuhan dan distribusi daging serta estimasi produktivitas karkas sapi hasil penggemukan. Disertasi Sekolah Pasca Sarjana. Institut Pertanian Bogor. Bogor

Hafid, H. 2008. Strategi pengembangan peternakan sapi potong di Sulawesi Tenggara dalam mendukung pencapaian swasembada daging nasional. Orasi Ilmiah Pengukuhan Guru Besar. Universitas Halu Oleo. Kendari.
Hafid, H., R.E. Gurnadi, R. Priyanto dan A.Saefuddin. 2010. Identifications of carcass chracteristic for estimating the comosition of beef carcass. Journal of the Indonesian Tropical Agriculture. 35(1): $22-26$.

Hafid, H. 2011. Pengantar Evaluasi Karkas. Cetakan Pertama. Penerbit Universitas Halu Oleo Press. Kendari.

Indra, W., Wiwin, T dan Tuti, W. 2015. Bobot potong, karkas, dan income over feed cost ayam Sentul jantan pada berbagai umur potong. Fakultas Peternakan. Universitas Padjadjaran. Bandung.

Kadiran dan B. Kushartono. 2005. Karkas ayam pedaging dari berbagai umur potong. Prosiding Temu Teknis Nasional Tenaga Fungsional Pertanian. Bogor.

Manurung, E. J. 2011. Performa ayam broiler pada frekuensi dan waktu pemberian pakan yang berbeda. Skripsi. Fakultas Peternakan. Institut Pertanian Bogor. Bogor.

Marlina, N. 2016. Persentase Karkas dan Bagian-Bagian Karkas Ayam Kampung pada Berbagai Umur. Skripsi. Jurusan Peternakan. Fakultas Peternakan. Universitas Halu Oleo. Kendari.

Soeparno. 2009. Ilmu dan Teknologi Daging. Gadjah Mada University Press, Yogyakarta.

Suhardi. 2011. Karakterisasi ex situ ayam lokal khas dayak bagi pengembangan plasma nutfah ternak unggas nasiona. Jurusan Peternakan, Fakultas Pertanian, Universitas Mulawarman. Samarinda. Jurnal Teknologi Pertanian,7(1):36-41. 